\title{
A Comparison of Energy and Thermal Performance of Rooftop Greenhouses and Green Roofs in Mediterranean Climate: A Hygrothermal Assessment in WUFI
}

\author{
Mansoureh Gholami, Alberto Barbaresi *, Patrizia Tassinari, Marco Bovo $\mathbb{D}$ \\ and Daniele Torreggiani \\ Department of Agricultural and Food Sciences, University of Bologna, 40126 Bologna, Italy; \\ mansoureh.gholami2@unibo.it (M.G.); patrizia.tassinari@unibo.it (P.T.); marco.bovo@unibo.it (M.B.); \\ daniele.torreggiani@unibo.it (D.T.) \\ * Correspondence: alberto.barbaresi@unibo.it
}

Received: 24 January 2020; Accepted: 15 April 2020; Published: 19 April 2020

check for updates

\begin{abstract}
In urban areas, a considerable proportion of energy demand is allocated to buildings. Since rooftops constitute one-fourth of all urban surfaces, an increasing amount of attention is paid to achieving the most efficient shapes and component designs compatible with every climate and urban context, for rooftops of varying sizes. In this study, three types of rooftop technologies, namely insulated, green roof, and rooftop greenhouse, are evaluated for energy and thermal performance using computer simulations. Water surface exposure, absorption, and intrusion are the three important factors in the calculation of hygrothermal models that impact energy consumption and building envelope performance; however, a few studies are specifically focused on providing realistic results in multi-dimensional hygrothermal models and the assessment of the impact of moisture in roofing solutions. This paper aims at evaluating the performance of three different roofing technologies through a two-dimensional hygrothermal simulation in software WUFI. To accomplish this, a precise localized microclimate model of a complex urban context on the scale of a neighborhood was employed to evaluate the cooling and heating loads of the buildings, the impact of the water content in the green roof on the thermal behavior of the roof surface, and the feasibility of designing a building with nearly zero cooling needs. A two-story building in the city center of Bologna, Italy is modelled. Simulation results have shown that during the cooling period, the performance of the designed rooftop greenhouse is the most effective by $50 \%$ reduction in cooling loads. Besides, the impact of moisture in green roofs has been detected as a negative factor for thermal and energy performance of the building in the Mediterranean climate. The results ultimately highlighted the capability of passively-designed rooftop greenhouses to create a building with nearly zero cooling needs.
\end{abstract}

Keywords: rooftop greenhouse; green roof; two-dimensional hygrothermal simulation; urban local microclimate modelling; green systems

\section{Introduction}

The energy consumption of urban buildings constitutes a considerable proportion of the world's energy demands. Thus, examining innovative strategies to create climate-conscious designs and harnessing the potential of urban areas to reduce the energy demand of urban buildings through controlling solar heat gains are increasingly attracting attention [1]. Since urban rooftops constitute $20 \%$ to $25 \%$ of the total urban surfaces [2], rooftop strategies are counted as among the most effective methods since they can provide a wide variety of benefits in various scenarios such as added insulation, 
structures of phase change materials, cool roofs, green roofs, rooftop greenhouses, water roofs, etc. Many European local governments are more and more interested in the implementation of these urban building strategies in order to make a net-zero energy vision achievable by 2020 [3]. Implementing these strategies is highly dependent on the construction and energy-saving systems but in general, the role of these roofs in saving energy varies; some of them just reduce heat transfer while others may impact the energy-saving rate through thermal inertia $[4,5]$.

Green roofs are increasingly attracting attention due to the wide range of benefits they provide, green roofs decrease urban temperature [6] and subsequently relieve the effect of urban heat islands in the cities [7]. Even on the roofs with photovoltaic installations, green roofs enhance electrical performance [8,9]. During the last decades, green roofs have been studied from a wide variety of aspects such as water runoff mitigation [10], aesthetic, or social impacts [11].

State of the Art

Several studies have focused on investigating the thermal-energetic performance of roofs, especially green roofs and insulated roofs. Green roofs are most common in Northern European countries as they enhance the effect of insulation and also save energy in hot and dry climates due to their thermal effect on heat transfer. The most significant feature of green roofs is the evapotranspiration of plants that provides a considerable cooling effect [12] especially on the upper floors of buildings [13]. An examination of the thermal behavior of an extensive green roof of a one-story building in Italy has been performed by Gagliano et al. [14] in which comfort level, energy consumption, and temperature reduction of a green roof have been compared to a traditional roof. The results showed a drop in the maximum temperature from 54.5 to $36{ }^{\circ} \mathrm{C}$ for green roofs. Sailor [15] simulated an EnergyPlus Environment for a green roof in two cities with different climate conditions; the results showed that green roofs improve electricity balance and increase gas consumption in winter. Following this model Silva et al. [16] examined the energy consumption of three types of green roofs and black and white roofs. The results showed that the best roof solution is the intensive one with $8 \mathrm{~cm}$ of insulation and the worst solution is the extensive one without insulation. A four-story building has been examined based on cooling, heating, lighting, occupation, and mechanical ventilation by Ferrante et al. [17]. They found out that green roof had a more stable temperature during the day and also a better performance in energy saving during the whole year. They also concluded that energy saving in the heating period is greater than in the cooling period [16]. Zeng et al. [18] developed an experimental simulation for the optimization of green roof features to optimize energy consumption; their results showed that the best thermal behaviour of the roof is achieved with an optimized thickness of the soil of 0.3 and a leaf area index (LAI) of 5. They have also proved that in hot arid climates green and cool roofs have the same results [19]. Huang et al. [20] examined the heat gain reduction and temperature fluctuation reduction of four kinds of green roofs in subtropical climates. Collins et al. [21] investigated in an experimental set up, the heat transfer reduction of bare and vegetated roofs in cold climates and especially when frozen. Another study, conducted by Jaffal and Ouldboukhitine [22] in France, proved that green roofs can be up to $6 \%$ effective in reducing energy needs [23,24]. There are other studies conducted in various climate conditions that have examined the functionality of green roofs in terms of thermal gain and their economic benefits. Economic feasibility of green roofs in different climates and for various rainfall and irrigation patterns has been examined in a modern office building and the simulation showed that, in hot climates, green roofs reduce cooling demand and in cold climates green roofs lead to less heating demand [25].

The majority of these studies were performed using one-dimensional heat transfer simulations. However, recently, new methodologies were used to improve the analysis and calculation. Still, developing more advanced methods of multi-dimensional modelling is necessary in order to yield results closer to the reality of the functionality of various roofing technologies in different climates.

Rooftop greenhouses are not a novel subject. However, there are only a few studies on their feasibility and functions in comparison to other methods. Greenhouses can benefit urban areas by 
providing food, energy, healthy environments, etc. There are many examples of these kinds of roofs built during the last decade: Gotham Greens, with a $1394 \mathrm{~m}^{2}$ roof area [26], The Vinegar Factory, built in 1993 [27], Sky Vegetables, with a $743 \mathrm{~m}^{2}$ area, built in 2013 [28], Public School [29] and Arbor House, with a $1000 \mathrm{~m}^{2}$ rooftop greenhouse [30] in New York, and Lufa Farms, built on a $31000 \mathrm{~m}^{2}$ roof area, in Montreal. There are also many examples in Europe, such as in Farming by Fraunhofer UMSICHT in Berlin, Newcastle University in the UK, The Hague of the UF002 De Schilde in Switzerland, the University of Barcelona in Spain, with a $128 \mathrm{~m}^{2}$ area, and Ferme Abattoir in Paris. Rooftop greenhouses can be integrated into buildings and take advantage of their heat waste as well as assist their energy-saving by creating shading and insulation on the roof. Despite the various cases that have been built over recent decades, there are just a few scientific studies that analyze their functions concerning the energy efficiency of buildings. In 2007, Caplow [31] examined the integration of rooftop greenhouses (RG) into buildings as a means for cooling. Nadal et al. [32] examined an actual case at the University of Barcelona from an energy-need and carbon-emission standpoint, using EnergyPlus, and, in a more recent study, he investigated the possibility of implementing RGs in a social housing neighborhood in Latin America [33]. The feasibility of using RGs in social houses in Tampines New Town for hydroponic farming has also been studied [34]. Benni et al. [35] analyzed the effects of the roof and opening configurations on temperature reduction in a greenhouse in hot climatic conditions.

Although the local climate has a direct impact on the energy loads of a building, few studies have examined roofing scenarios in the context of the building. Most studies have been limited to macroscale climate modelling. However, there are many local parameters, such as the urban heat island effect in every urban area that can impact both cooling and heating loads and actual local temperatures. Further attempts are needed to bring energy simulation results closer to reality. Notably, simulation in one-dimensional models neglects some important parts of energy simulation and simplifies the heat transfer in different layers and shapes to remarkably reduce the simulation time. To overcome these limitations and achieve more realistic results, a two-dimensional hygrothermal simulation has been developed in the software WUFI (Wärme Und Feuchte Instationär in German) by which water surface exposure, absorption, and intrusion are examined to model rainfall, irrigation, and moisture in the roof materials. In addition, an accurate localized weather model has been developed to take into consideration the impact of urban context on microclimate conditions.

To accomplish this, the next section will explain the methodology and will review the details of hygrothermal calculation for green roofs and rooftop greenhouses. In Section 3, the results will be analyzed and the details of the simulation will be explained. Section 4 concludes the study with recommendations for future research.

\section{Materials and Methods}

This paper presents a modelling methodology by which a multi-dimensional hygrothermal simulation, based on actual local weather modelling, can be accomplished. Using this methodology, a comparison was made between insulation, green roofs, and rooftop greenhouses to analyze energy performance and thermal behavior of buildings. Different aspects of roofing scenarios were analyzed in four steps: energy calculation, impact of moisture on the thermal behavior of the building, thermal performance of passive-designed rooftop greenhouse, and the zero-cooling need of the building. After examining various options for this modelling and considering that roofs must be simulated in one software for a valid comparison, WUFI [36] was chosen to perform the simulation. WUFI calculates heat and moisture exchanges between the building envelope and the surroundings. It uses a precise precipitation database and a calibrated moisture transport and calculates vapor diffusion and liquid water transport. In this work, air-conditioning in summer is always simulated by an electricity-driven chiller, and for a heating system, a gas-fired boiler is performed during all simulations. In every time step, WUFI calculates the hygrothermal loads according to equations based on the Thomas algorithm. Furthermore, WUFI Plus can perform indoor air modelling and can model space heating and cooling, which makes it suitable for greenhouse simulation. 


\subsection{Climate}

This paper employed a comprehensive modelling methodology to represent the actual local weather conditions. A localized weather file was used in the modelling, which provided the meteorological, urban morphological, reference site, and urban geometry features for consideration [37]. To accomplish the representation, the Urban Weather Generator (UWG) [38] was employed in order to generate a weather file including both hourly urban canopy air temperatures and a humidity dataset from a regular weather file. It took into consideration the vegetation, urban building and road surface materials, horizontal building density, and vertical-to-horizontal built ratio. The chosen neighborhood for the reference building was in the city of Bologna and was modelled with all the details. The source of this weather file is a close weather station named "urban Bologna" [39] and is based on the on the year-round records of 2018 and 2019. The output of the model showed differences in maximum and minimum temperature and also in heating and cooling degree days. Since the precision of every simulation is directly affected by the accuracy of input data, inputting the actual local weather data improves the accuracy of the hygrothermal simulation as well as the analysis of the results in various scenarios.

\subsection{Green Roof}

In energy modelling, green roofs are generally subdivided into three fundamental components: protection structure, soil, and canopy or vegetation cover [13]. Canopies consist of leaves and also the air between them. Canopies are characterized by two features: the height of the plants and the leaf area index. The soil contains three phases of matter: solid, gas (air and water vapor), and liquid (water). A system drawing of the investigated green roof in this study is shown in Figure 1 and detailed measures are presented in Table 1.

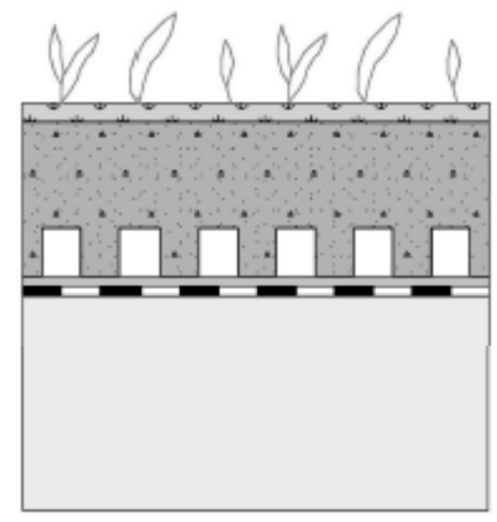

sedum planting

aubatrate type $\mathrm{M}$ incl.

drainage board FKD 25

protection mat

Figure 1. System drawing of investigated green roof (image taken from WUFI archive).

Table 1. Hygrothermal properties of the green roof.

\begin{tabular}{cccc}
\hline Hygrothermal Parameters & Sedum Planting & Substrate & Protection Mat \\
\hline Bulk density $\mathrm{kg} / \mathrm{m}^{3}$ & 1500 & 405 & 83 \\
\hline Porosity & 0.5 & 0.82 & 0.95 \\
\hline Specific heat capacity $\mathrm{J} / \mathrm{kg} \mathrm{K}$ & 1000 & 1000 & 840 \\
\hline Thermal conductivity, dry, $10 \mathrm{c} / 50 \mathrm{~F} \mathrm{~W} / \mathrm{m} \mathrm{K}$ & 0.2 & 0.4 & 0.035 \\
\hline Water vapor diffusion resistance factor & 5 & 3 & 1 \\
\hline Typical built-in moisture $\mathrm{kg} / \mathrm{m}^{3}$ & 1 & 4.2 & 0.7 \\
\hline Reference water content $\mathrm{kg} / \mathrm{m}^{3}$ & 12 & - & - \\
\hline Free water saturation & 300 & - & $2 \cdot 10^{-4}$ \\
\hline $\begin{array}{c}\text { Temperature-Dependent thermal } \\
\text { conductivity supplement } \mathrm{W} / \mathrm{m} \mathrm{K}\end{array}$ & $2 \cdot 10^{-4}$ & $2 \cdot 10^{-4}$ & 0.02 \\
\hline Thickness $(\mathrm{m})$ & 0.01 & 0.1 &
\end{tabular}


Green roof modelling can be classified into one-dimensional and multi-dimensional modelling. One-dimensional modelling simplifies thermal transfer into different layers, which can be simulated faster and are more common in energy modelling [40]. However, multidimensional modelling aims to model thermal effects and geometry inputs more accurately, although the simulation takes a longer time in comparison to the one-dimensional modelling of green roofs and walls. Although intersections or curved shapes can only be modelled through two-dimensional modelling, Busser et al. [41] have shown that the accuracy of thermal behavior is improved by $30 \%$ to $40 \%$ in multi-dimensional modelling, especially in contemporary buildings.

The most common model that has been employed to model green roofs is the "Fast All-Season Soil Strength"(FASST) [42]. In FASST, there are two distinct equations which calculate the heat flux of soil (Equation (1)) and foliage (Equation (2)). The heat fluxes in this model consist of absorbed solar radiation, long-wave radiation between leaves, sky, and soil.

$$
\begin{gathered}
F_{f}=\sigma_{f}\left[I_{s}\left(1-r_{f}\right)+\varepsilon_{f} \sigma I_{i r}-\varepsilon_{f} \sigma T_{f}^{4}\right]+\frac{\sigma_{f} \varepsilon_{g} \varepsilon_{f} \sigma}{\varepsilon_{1}}\left(T_{g}^{4}-T_{f}^{4}\right)+H_{f}+L_{f} \\
F_{g}=\left(1-\sigma_{f}\right)\left[I_{s}\left(1-r_{g}\right)+\varepsilon_{g} \sigma I_{i r}-\varepsilon_{g} \sigma T_{g}^{4}\right]+\frac{\sigma_{f} \varepsilon_{g} \varepsilon_{f} \sigma}{\varepsilon_{1}}\left(T_{g}^{4}-T_{f}^{4}\right)+H_{g}+L_{g}+\mathrm{k} \frac{\partial T_{g}}{\partial z}
\end{gathered}
$$

While this model has been reliable enough to be employed by EnergyPlus [43], it does not take into account the variations in soil thermal properties, including thermal conductivity, specific heat capacity and density, and solar reflection, when calculating. Furthermore, it is not capable of accurately representing the moisture accumulation on roofs. Moreover, the precipitation data provided in the EnergyPlus weather database are considered not accurate for the purposes of this paper. The equation employed in WUFI (Equation (3)) included initial temperature, relative humidity (RH), radiation, precipitation, wind speed and direction, and initial construction moisture [36]. A detailed modelling procedure in WUFI is shown in Figure 2.

$$
\frac{\partial H}{\partial T} \cdot \frac{\partial T}{\partial t}=\nabla \cdot(\lambda \nabla T)+h_{v} \nabla \cdot\left(\delta_{p} \nabla\left(\varnothing p_{\text {sat }}\right)\right)
$$

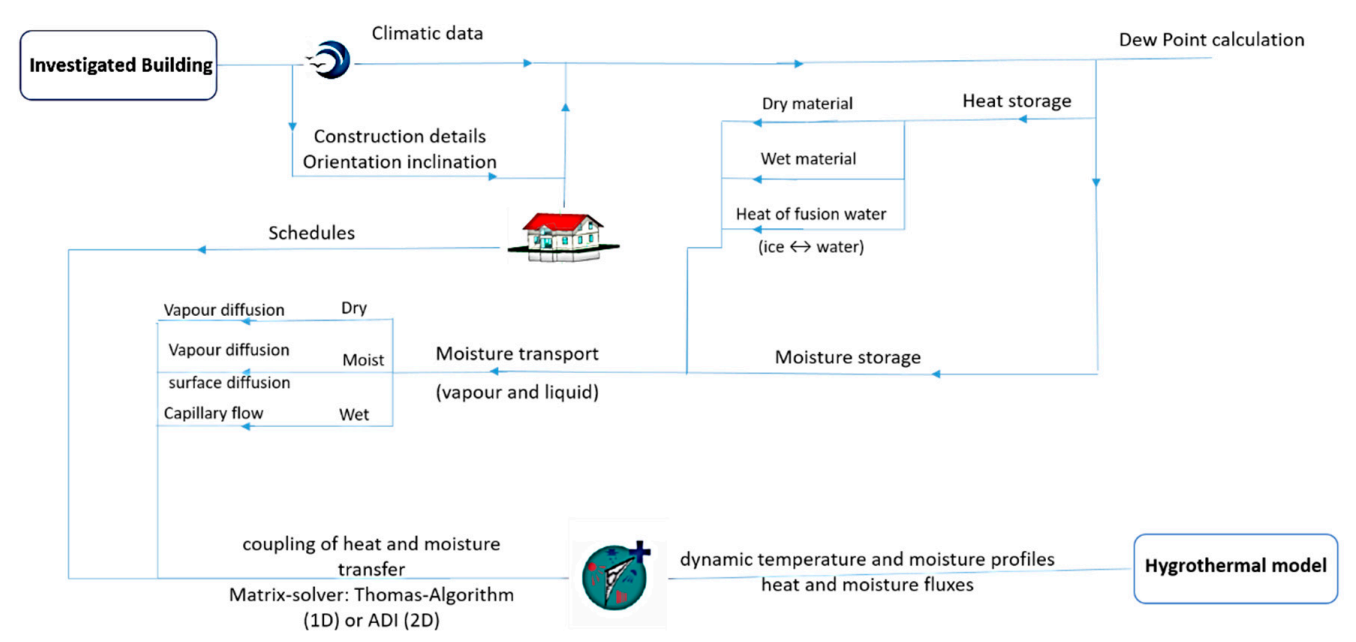

Figure 2. The steps of the hygrothermal modelling in WUFI.

\subsection{Rooftop Greenhouse}

As a kind of building-integrated agriculture, rooftop greenhouses are cultivation systems which are enclosed to urban rooftops in an environmentally monitored and controlled area. Passive cooling and heating strategies benefit rooftop greenhouses. Rooftop greenhouses can act as a heating system and relieve the direct solar gain of the surface of the roof in summer and also in winter to create a 
space sheltered from the cold airflow. The proposed rooftop greenhouse scenario enhances the energy efficiency of buildings by providing a specific design for the shape, openings, and shadings of the greenhouse to take advantage of the green roof and the insulation and can also provide the means of environmentally sustainable food production. This design is completely in line with passively designed strategies in a Mediterranean climate. In this type of climate zone, summers are mostly hot and humid and winters are cold. The rooftop greenhouse modelled in this study was $12 \mathrm{~m}$ wide and $20 \mathrm{~m}$ long, with windows that could open up to 45 degrees to provide ventilation in the summer. Its structure was made up of wooden frames and glazing glasses with a low- $\varepsilon$ coating and a shading coefficient of 0.39 . An attached shading cloth covers the east side of the ceiling during summer days. The properties of the rooftop greenhouse are presented in Tables 2 and 3 and Figure 3 shows the form details of the proposed rooftop greenhouse.
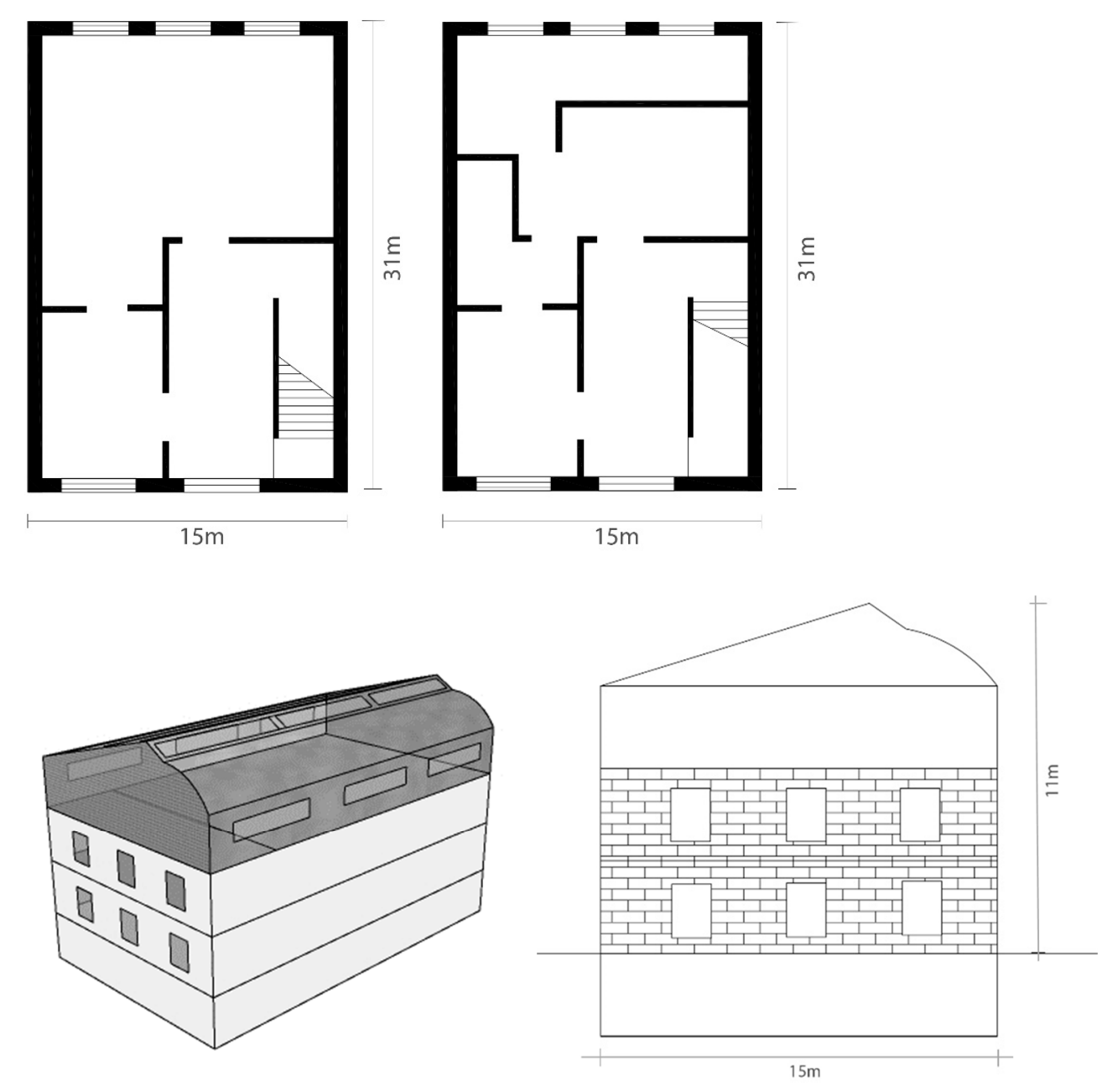

Figure 3. Investigated building model.

Table 2. Thermal properties of ceilings, walls, and structural roof in the investigated buildings.

\begin{tabular}{ccc}
\hline Element & Thickness $(\mathbf{m})$ & U-Value $\left(\mathbf{W} / \mathbf{m}^{\mathbf{2}} \mathbf{K}\right)$ \\
\hline Wall & 0.265 & 0.512 \\
\hline Ceiling & 0.41 & 0.970 \\
\hline Roof & 0.30 & 0.523 \\
\hline
\end{tabular}


Table 3. Properties of the rooftop greenhouse.

\begin{tabular}{cc}
\hline Parameter & Value \\
\hline Gross volume & $1060 \mathrm{~m}^{3}$ \\
\hline Total external surface & $302 \mathrm{~m}^{2}$ \\
\hline Glazed surface & $302 \mathrm{~m}^{2}$ \\
\hline Roof surface & $240 \mathrm{~m}^{2}$ \\
\hline Roof surface/total external surface & 0.79 \\
\hline
\end{tabular}

\subsection{Model Description}

The methodology was carried out on a two-story residential building. The building was modelled based on an Italian national document of typology approach for building stock energy assessment (TABULA) [44] as a representative of Italian building. The modelled parameters of the building are classified and shown in Table 2 and Figure 3. The building was simulated through three roof scenarios: baseline roof, insulated roof, green roof, and a rooftop greenhouse. The building information, including geometry, construction, and schedules, were modelled manually in WUFI.

\section{Results and Discussion}

The building was modelled in WUFI, using three scenarios: insulated, green roof, and a rooftop greenhouse. The simulations were performed to calculate the annual heating and cooling loads in the same local climate conditions. The energy-saving estimation of the scenarios was extracted and compared to the baseline building design. The simulations were applied in 15-min steps. The impact of the moisture on the reduction of energy loads and also the possibility of designing a non-cooling building were analyzed.

\subsection{Energy Needs}

One of the main advantages of these technologies concerns the improvement of energy-saving during cooling and heating periods of the year. In this paper, this impact will be considered as primary energy needs. During the cooling period, air conditioning is provided with an electrical chiller and during the heating period, heating is provided by a gas boiler. The simulation results show that all roofing solutions reduce the total energy needed for cooling and heating (Figure 4). The best performances came, first, from the insulated roofs that showed an improvement of about $20 \%$ and, second, from the rooftop greenhouse scenario with approximately $15 \%$ energy saving in the annual heating and cooling loads of the building. The green roof also has shown a 7\% improvement in energy saving in comparison to the baseline roof.

During heating periods (Nov, Dec, Jan, Feb), the best roofing solution is the insulated roof and the functionality of green roofs (by $5 \%$ reduction in heating loads) is at the lowest level due to the humidity and the moisture that directly affect the heat flux rate; however, in cooling periods, green roofs have a better impact on cooling loads as well as on the temperature of the roof. Rooftop greenhouses in the heating period perform slightly better than green roofs; it is worth noting that the rooftop greenhouse during the heating period is simulated with no opening and shading.

As observed, during the cooling period (Jun, July, August), the performance of the designed rooftop greenhouse is the most effective by $50 \%$ reduction since it provides shading, insulation by soil, and also airflow through openings, which consequently leads to a cooler roof surface during the summer. It is a common belief that green coverage always improves energy needs for cooling; nevertheless, the hygrothermal model shows that, in a Mediterranean climate, the moisture in green roofs can adversely impact the cooling loads. However, in this period insulated and green roofs showed approximately the same improvement in energy needs. 


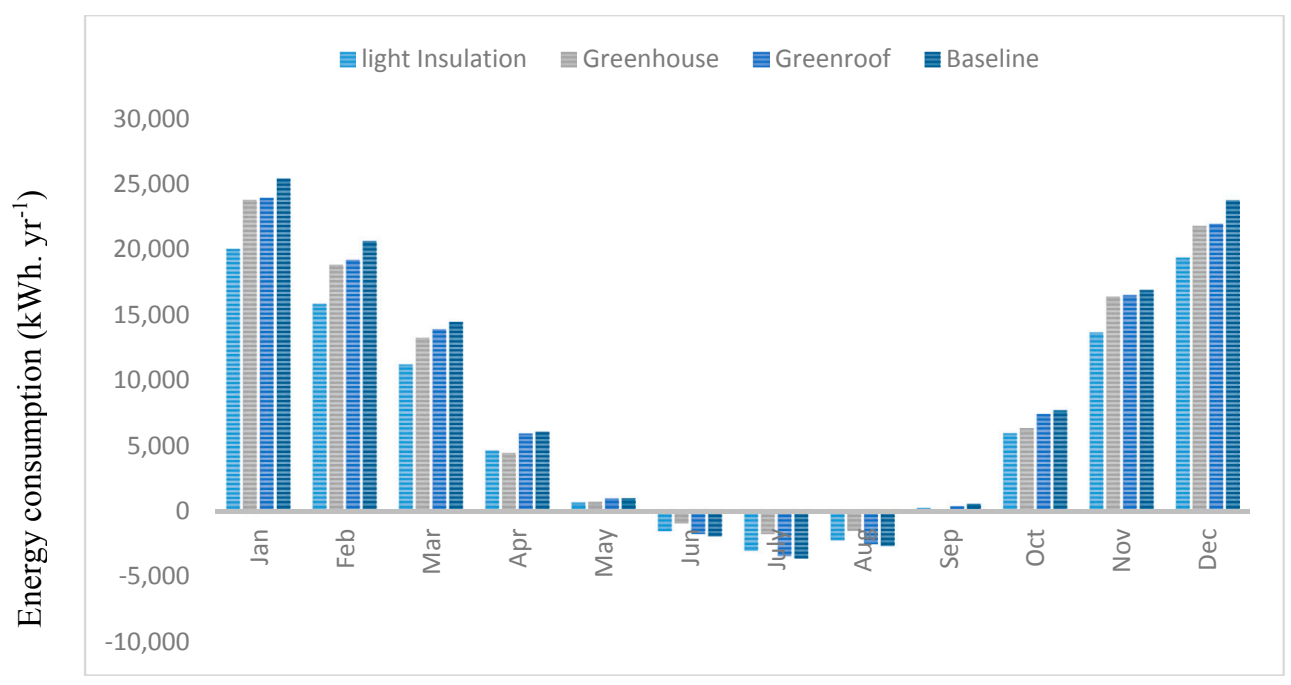

Figure 4. Monthly energy consumption of different roof scenarios $\left(\mathrm{kWh}^{\mathrm{yr}} \mathrm{yr}^{-1}\right)$.

\subsection{The Impact of Moisture on the Green Roof Performance}

Although modelling results are affected by local microclimates, they are highly dependent on rooftop structures and greening systems. While the structural elements of insulated rooftops are fixed during different seasons (static), green roof elements and, subsequently, their performance are highly dependent on climate conditions (dynamic). In fact, the amount of moisture in green roofs affects the level of insulation. Surface wetness is one of the factors that has been, in a limited number of studies, considered in measurements or as a fixed parameter in evaporation efficiency, evaporation ratio, and water vapor conductivity. By increasing the level of water content, thermal conductivity and specific heat of the green roof get enhanced (Figure 5). As a matter of fact, when irrigation is applied to the roof, water content is converted and performs as heat [45]. Thus, the amount of water needed for evapotranspiration is an important factor in green roof evaluation. In this study, a green roof was modelled on three levels of moisture, namely, actual rainfall, the maximum amount of water, and dry.

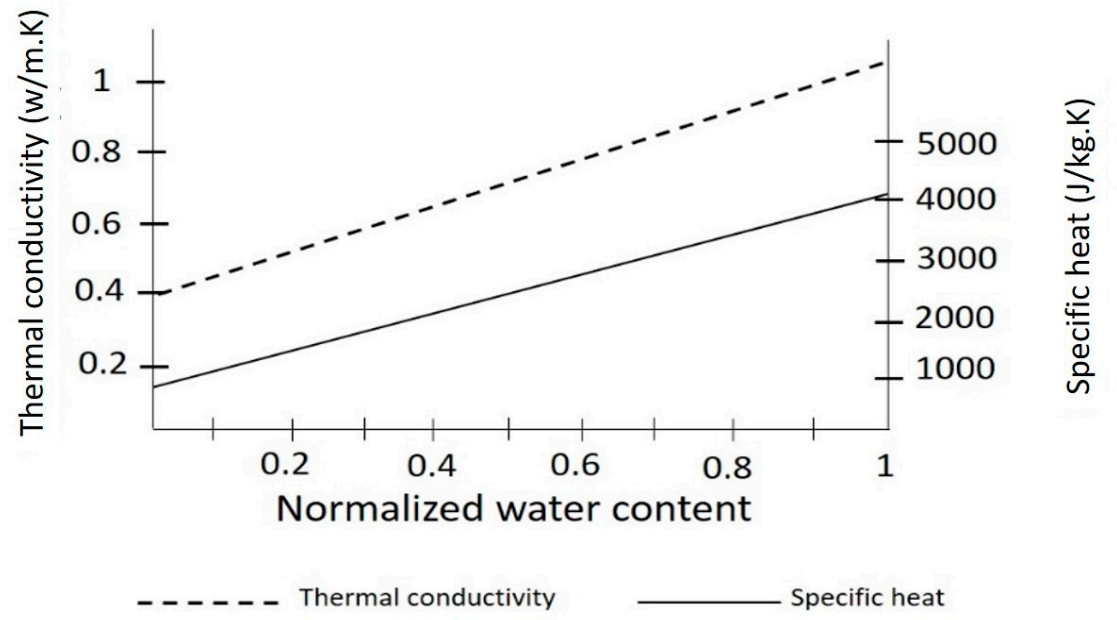

Figure 5. Moisture dependent properties of the green roof substrate.

Figure 6 shows the heating and cooling loads in three configurations during heating and cooling periods. In this case study, due to the Mediterranean climate of Bologna, water can adversely impact the heating load in winter, as the results show the green roof in maximum rainfall in the heating period acts nearly equal to the baseline roof with more than $6000 \mathrm{~kW}$ monthly energy consumption. This point is important since it highlights that green coverage of roofs is not always as an energy-saving strategy. The dry green roof, however, achieved the best functionality by $18 \%$ improvement in the level of energy 
load. The reason is that soil acts as an insulation layer in the roof, while the higher the level of moisture in green roofs, the less energy-efficient they become in this climate. On the other hand, in summer, the level of the cooling load increases when the wetness of the green roof decreases. This is obviously due to the evaporation of water content that decreases the temperature (endothermic reaction) of the surface and consequently affects the cooling load of the building. It is worth noting that these results are highly variable in various climates.

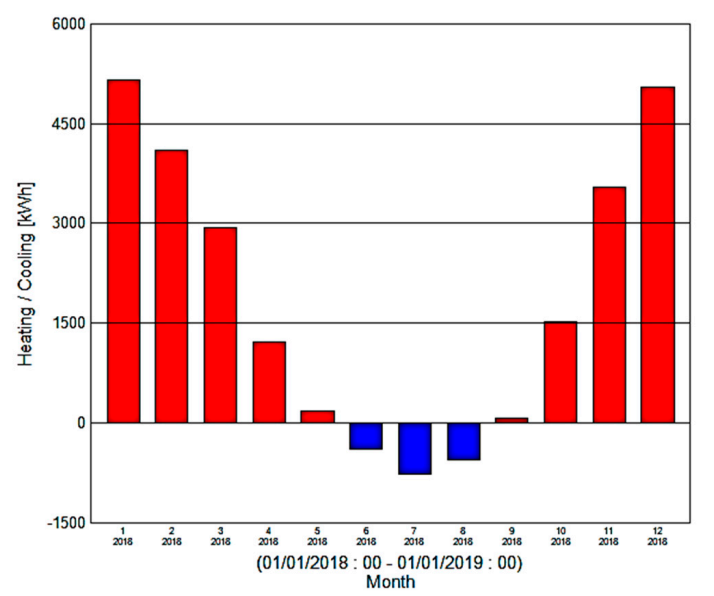

(a) Dry green roof.

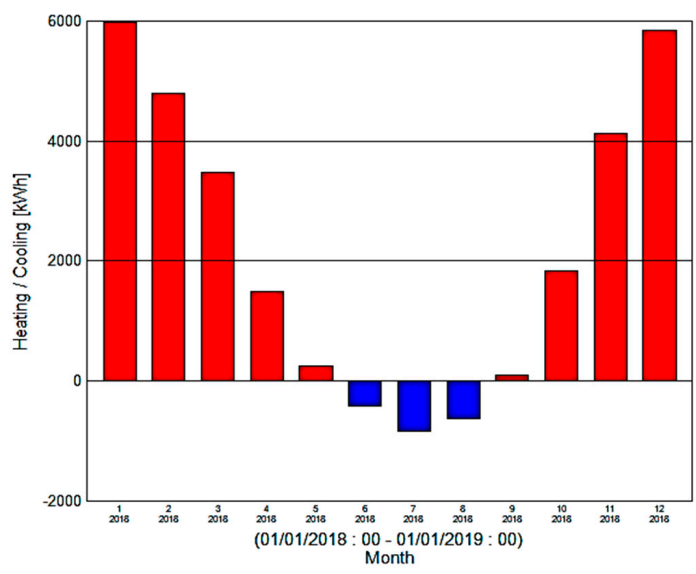

(b) Green roof in actual rainfall.

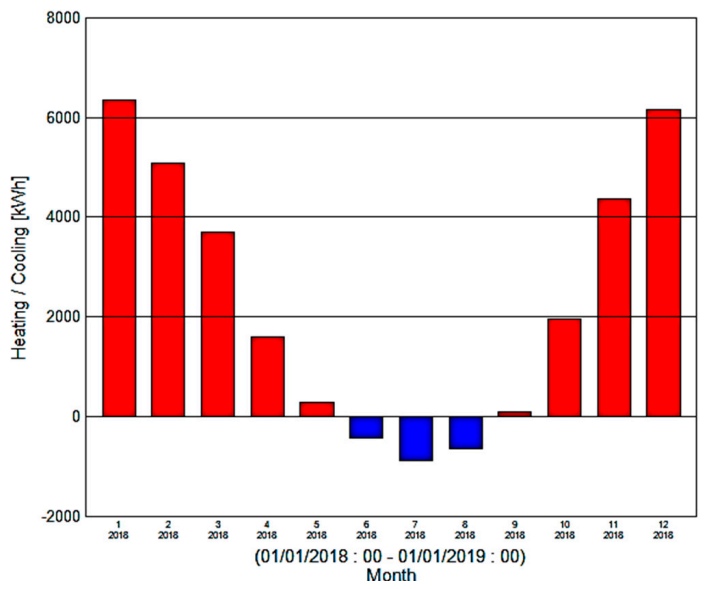

(c) Green roof in maximum rainfall.

Figure 6. Heating and cooling performance of green roofs with different levels of moisture, cooling loads are in blue and heating loads are in red. (a) Dry; (b) actual rainfall; (c) maximum rainfall. 


\subsection{Rooftop Greenhouse Space Performance}

The rooftop greenhouse was explicitly examined for providing an optimal condition $\left(12-26^{\circ} \mathrm{C}\right)$ for the thermal needs of a greenhouse and the cultivation conditions. During the heating period, passively-designed rooftop greenhouse is simulated with opening and shading on the ceiling to limit solar gain while in winter, it is simulated without opening and shading to maximize the solar gain. Table 4 shows the mean, maximum, and minimum monthly temperatures of the rooftop greenhouse and outdoor temperature. In the cooling period of the year, the mean temperature of exterior air was the highest in July with $24{ }^{\circ} \mathrm{C}$ while the peak temperature was $34{ }^{\circ} \mathrm{C}$ temperature. The minimum temperature in the cooling period was $6^{\circ} \mathrm{C}$ in the beginning days of May. The indoor temperature of the rooftop greenhouse in this period showed a maximum of $36^{\circ} \mathrm{C}$ in July while the mean temperature was still at $25^{\circ} \mathrm{C}$.

Table 4. Monthly average, minimum and maximum of rooftop greenhouse and outdoor temperature.

\begin{tabular}{ccccccc}
\hline \multirow{2}{*}{ Month } & \multicolumn{2}{c}{$\begin{array}{c}\text { Temperature of Interior Air in the } \\
\text { Rooftop Greenhouse }\left({ }^{\circ} \mathbf{C}\right)\end{array}$} & \multicolumn{3}{c}{ Temperature of Exterior Air $\left({ }^{\circ} \mathbf{C}\right)$} \\
\cline { 2 - 7 } & Mean & Max & Min & Mean & Max & Min \\
\hline Jan & 3.22 & 15.67 & -2.15 & 1.12 & 10.46 & -12.98 \\
\hline Feb & 5.62 & 18.14 & -1.48 & 3.32 & 15.49 & -5.90 \\
\hline March & 10.81 & 23.48 & -0.80 & 8.12 & 20.69 & -1.16 \\
\hline April & 14.96 & 27.00 & 3.98 & 12.72 & 23.16 & 3.00 \\
\hline May & 19.31 & 30.86 & 6.67 & 17.49 & 27.19 & 6.49 \\
\hline Jun & 23.40 & 35.83 & 13.37 & 21.39 & 32.99 & 12.20 \\
\hline July & 25.94 & 36.37 & 13.39 & 24.91 & 34.80 & 12.03 \\
\hline Aug & 25.27 & 35.01 & 11.98 & 23.57 & 34.80 & 11.01 \\
\hline Sept & 20.88 & 32.04 & 9.07 & 19.70 & 30.20 & 8.11 \\
\hline Oct & 15.32 & 25.23 & 6.87 & 13.71 & 23.96 & 4.43 \\
\hline Nov & 10.46 & 19.01 & -0.70 & 7.22 & 18.59 & -1.70 \\
\hline Dec & 6.88 & 13.83 & -3.48 & 2.64 & 14.09 & -5.16 \\
\hline
\end{tabular}

Outdoor mean air temperature in the heating period varied from 1 to $13^{\circ} \mathrm{C}$. The minimum decreased to $-12^{\circ} \mathrm{C}$ and the warmest days were allocated to April and October with a maximum temperature of $23^{\circ} \mathrm{C}$. On the other hand, inside the rooftop greenhouse, the average of "mean temperature" was $9{ }^{\circ} \mathrm{C}$ during the heating period, however, it fluctuated between the lowest temperature of $-3^{\circ} \mathrm{C}$ in December and maximum of $27^{\circ} \mathrm{C}$ in April.

To assess the indoor climate condition for thermal needs of a greenhouse, the total hours of overheated and overcooled were counted. The total hours with a temperature above $27^{\circ} \mathrm{C}$ constituted less than $7 \%$ of the year and the total of overcooled hours was up to $28 \%$, from which just $6 \%$ accounted for the hours with a temperature less than $7{ }^{\circ} \mathrm{C}$. Figure 7 shows more detailed weather data of overheated and overcooled hours in the rooftop greenhouse.

Considering cultivation condition, during the overcooled and overheated period, the rooftop greenhouse needs to be controlled in air temperature when it is outside of the $12-26{ }^{\circ} \mathrm{C}$ range. A functional solution for preventing this drop in temperature during winter nights, as investigated by [32], is installing an air ventilation channel from the heated zone of the building to the greenhouse. This enables the reuse of heated air for the greenhouse. 


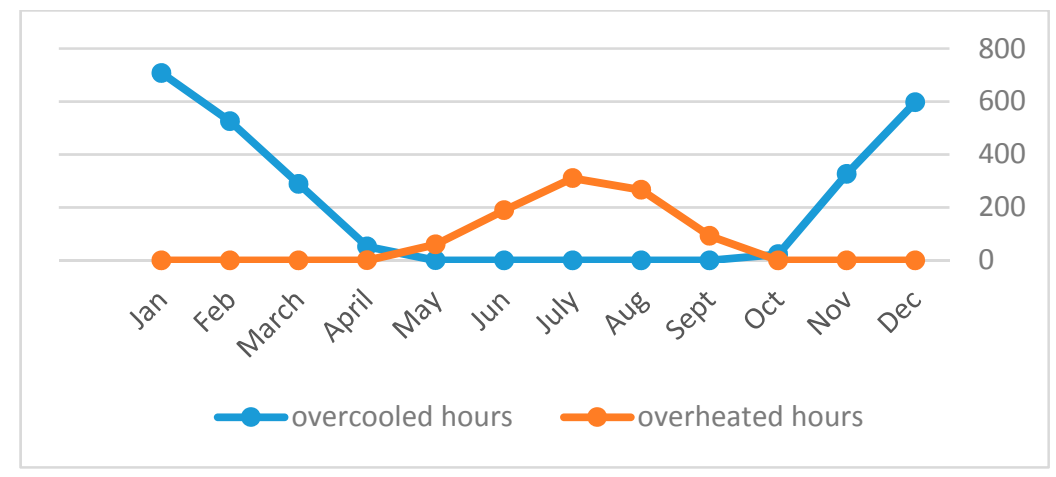

Figure 7. Total overheated and overcooled hours of the rooftop greenhouse.

\subsection{The Possibility of the Nearly Zero Cooling Need Scenario}

Roof configuration is one of the most effective elements in the reduction or even elimination of cooling load in buildings during the period of peak air temperature in summer. Barbaresi et al. [46,47] examined the possibility of eliminating the conditioning system in a winery and this study uses the same strategy in optimizing or even avoiding conditioning systems. To analyze the feasibility of this scenario, the roof solutions were examined in the operative temperature of residential zones. Figure 8 shows the comparison between the average of operative temperatures in the proposed roofing solutions and outdoor temperature in the peak air temperature period in summer. While outdoor mean air temperature is between 32 and $33^{\circ} \mathrm{C}$, the indoor mean air temperature of the building with all the roofing technologies is less than $29^{\circ} \mathrm{C}$ and the minimum temperature is allocated to rooftop greenhouse which is within the range of $26^{\circ} \mathrm{C}$ to $28^{\circ} \mathrm{C}$. Green roofs with an actual level of rainfall and insulated roofs have shown approximately similar results between 28.5 and $30^{\circ} \mathrm{C}$.

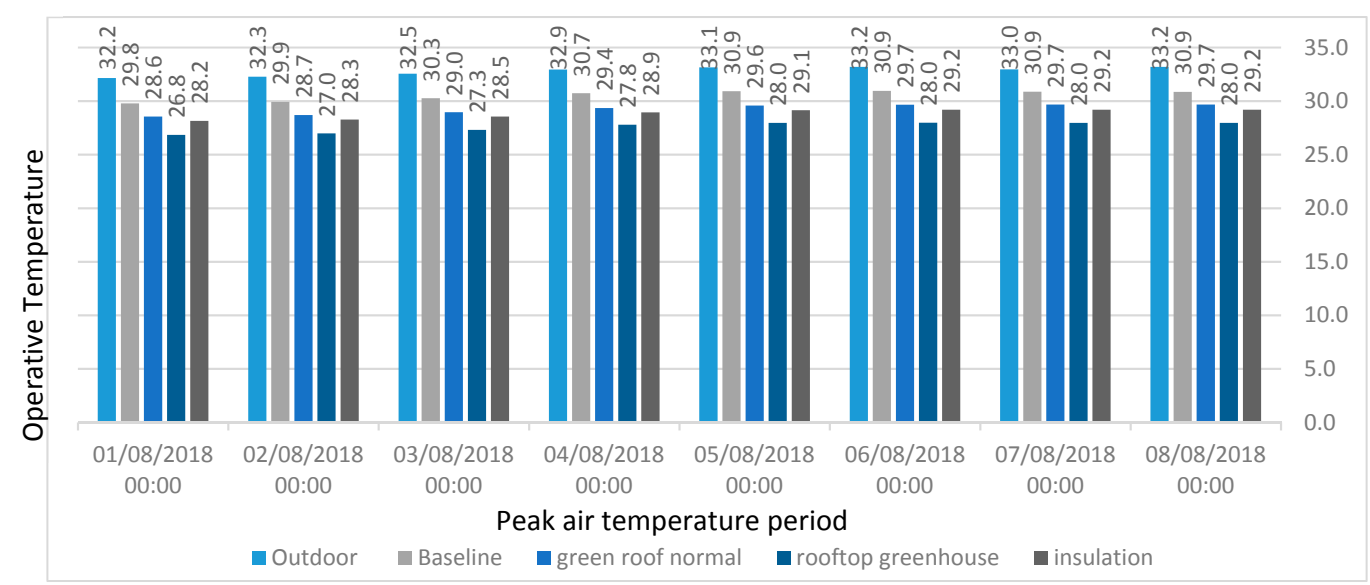

Figure 8. Operative temperature in various scenarios during peak air temperature period.

Figure 9 shows the total hours with an operative temperature above $27,28,29$ and $30^{\circ} \mathrm{C}$. The results from the passively-designed rooftop greenhouse indicate that the percentages of the hours with an operative temperature of more than $28{ }^{\circ} \mathrm{C}$ was less than $35 \%$ which is relatively $18 \%$ of the peak period of air temperature. As has been shown in Figure 8, passively-designed rooftop greenhouses are by far the most effective and responsive solution to a non-cooling scenario. After the rooftop greenhouse, there are insulated roofs with $184 \mathrm{~h}$ above $28^{\circ} \mathrm{C}$ and green roof with nearly $132 \mathrm{~h}$ above $29^{\circ} \mathrm{C}$. 


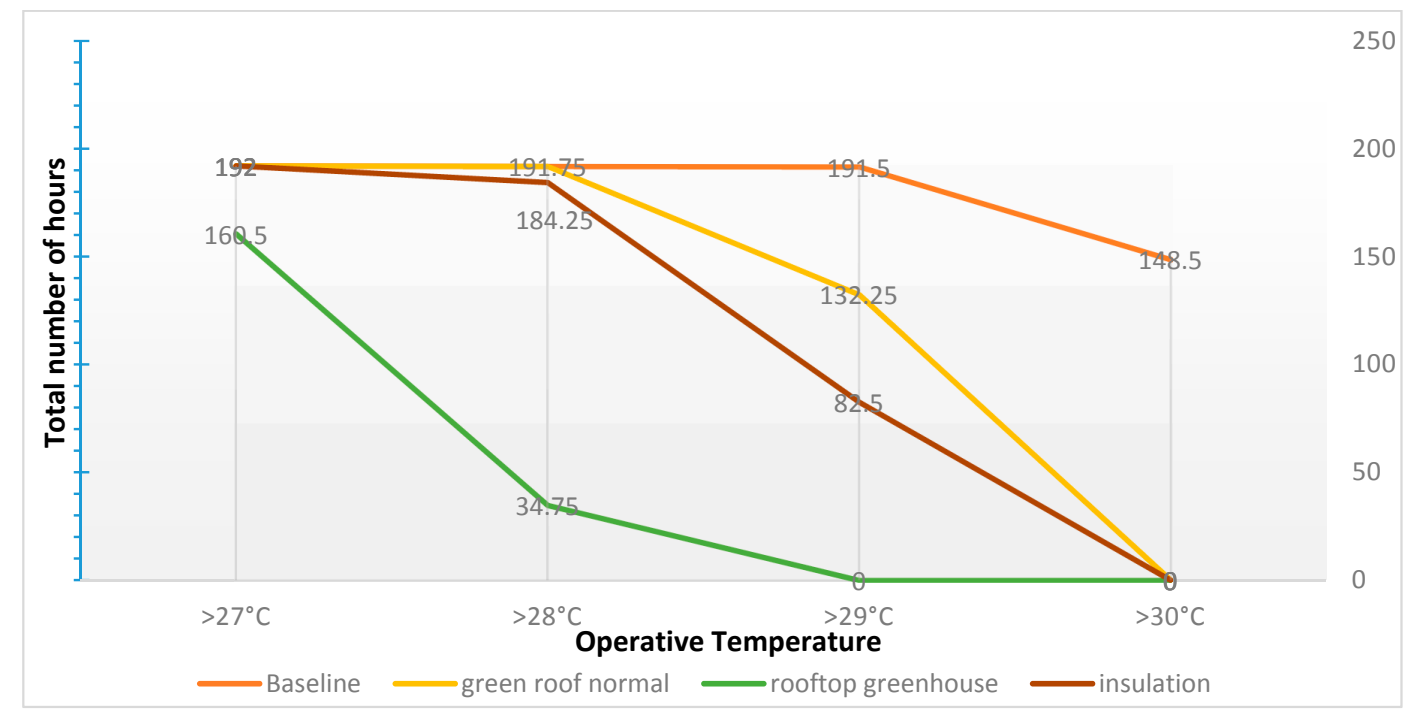

Figure 9. Total hours with operative temperature above $26^{\circ} \mathrm{C}$ in various scenarios during peak air temperature period.

\section{Conclusions}

This paper aimed to present an accurate methodology for analyzing three roof scenarios, namely insulated roof, green roof, and rooftop greenhouse. The scenarios were examined through two-dimensional hygrothermal models in WUFI simulations on a building in Bologna, Italy. This study specifically focused on refining the methodology for analyzing buildings' energy performance. First, the microclimate of the location was calculated using the Urban Weather Generator to obtain the details of meteorological features, urban morphology, reference site, and urban geometry parameters, as they directly affect building energy loads. Furthermore, a two-dimensional hygrothermal simulation was developed through WUFI, which, in comparison to one-dimensional simulations, enhances the level of accuracy in simulating thermal behavior by including precipitation effects, the impact of moisture on materials, and special forms of the elements used in buildings. The results of the simulation were examined and divided in four topics: (a) energy calculation, (b) the impact of moisture on the thermal behavior of the building, (c) thermal performance of passive-designed rooftop greenhouse, and (d) zero-cooling need buildings. The results of the annual energy performance of the building provided interesting findings. In general, roofing scenarios showed different functionality in various conditions. While in the cooling period of the year the rooftop greenhouse was the most effective solution, during the heating period the least functionality was shown by the green roof. The developed model proved that moisture in green roofs adversely impacts the energy performance of the green roofs in the Mediterranean climate; this means the more the level of the water content of the layers increases, the less energy-saving it gets. Moreover, the specific passive form of the proposed rooftop greenhouse is effectively responsive in controlling indoor thermal behavior to achieve a nearly zero-cooling need building.

The present work represents a contribution to plan strategies oriented at reducing the energy consumption at building and urban scales. The study analyzes scenarios that are considered representative for the investigated area, providing researchers and professionals with a valid methodology to define the best energy-saving solutions. This work is seen as a baseline for wider research that involves more comprehensive strategies that are not limited to energy reduction but include also energy production (such as the installation of photovoltaic and/or solar panels). All those interventions-active and passive - should be evaluated by using the same methodology and by taking into account several scenarios. For this reason, further research is needed about the application of this methodology to a group of buildings, with the aim of showing how a mix of these roofing solutions 
can work together on a macro scale to create the most responsive solution in an urban context. Finally, a strategy for economic analysis should be identified to complete the study.

Author Contributions: Conceptualization, M.G. and A.B., D.T.; Formal analysis, M.G.; Investigation, M.G. and A.B.; Methodology, M.G. and A.B.; Project administration, P.T. and D.T.; Resources, P.T. and D.T.; Software, M.G.; Supervision, A.B., P.T. and D.T.; Validation, M.G.; Visualization, M.G., A.B. and M.B.; Writing-original draft, M.G.; Writing-review \& editing, M.G., A.B., M.B., D.T. All authors have read and agreed to the published version of the manuscript.

Funding: This work was not funded by any government agency, industry or other philanthropic organization.

Conflicts of Interest: The authors declare no conflict of interest.

\section{Nomenclature}

\begin{tabular}{llll}
\multicolumn{2}{c}{ Variables } & & Greek letters \\
$\mathrm{A}$ & Roof Surface $\left[\mathrm{m}^{2}\right]$ & $\varepsilon$ & Thermal emissivity $[-]$ \\
$\mathrm{F}$ & Net heat flux $\left[\mathrm{W} \cdot \mathrm{m}^{-2}\right]$ & $\varepsilon 1$ & View factor \\
$\mathrm{Is}$ & Total incoming short wave radiation $\left[\mathrm{W} \cdot \mathrm{m}^{-2}\right]$ & $\eta$ & Efficiency \\
$\mathrm{r}$ & Solar reflectance & $\mathrm{p}$ & Density of air $\left[\mathrm{kg} \cdot \mathrm{m}^{-3}\right]$ \\
$\mathrm{I}$ & Total incoming longwave radiation $\left[\mathrm{W} \cdot \mathrm{m}^{-2}\right]$ & $\sigma$ & Stefan-Boltzmann constant $\left[\mathrm{W} \cdot \mathrm{m}^{-2} \cdot \mathrm{K}{ }^{-4}\right]$ \\
$\mathrm{H}$ & Sensible heat flux $\left[\mathrm{W} \cdot \mathrm{m}^{-2}\right]$ & $\partial$ & partial derivatives \\
$\mathrm{L}$ & Latent heat flux $\left[\mathrm{W} \cdot \mathrm{m}^{-2}\right]$ & $\sigma_{\mathrm{f}}$ & Fractional vegetation coverage \\
$\mathrm{k}$ & Dry soil thermal conductivity $\left[\mathrm{W} \cdot \mathrm{m}^{-1} \cdot \mathrm{K}^{-1}\right]$ & $\delta_{p}$ & vapour permeability \\
$\mathrm{T}$ & Temperature $[\mathrm{K}]$ & $\lambda$ & Fictitious thermal conductivity \\
$\mathrm{t}$ & Time [h] & $\nabla$ & gradient of a divergence \\
$p_{\text {sat }}$ & Saturation pressure $[\mathrm{Pa}]$ & & Subscripts \\
$\mathrm{h}$ & Enthalpy $\left[\mathrm{J} \cdot \mathrm{m}{ }^{-3}\right]$ & $\mathrm{f}$ & Foliage layer \\
LAI & Leaf Area index & $\mathrm{g}$ & Soil layer \\
FKD & Fest Körper Dränagen(Firm Body Drainage) & $\mathrm{sat}$ & Saturation \\
$\mathrm{HVAC}$ & heating, ventilation, and air conditioning & $\mathrm{v}$ & Relative to vapour
\end{tabular}

\section{References}

1. Asadi, E.; Gameiro, M.; Henggeler, C.; Dias, L.; Glicksman, L. Multi-objective optimization for building retrofit : A model using genetic algorithm and artificial neural network and an application. Energy Build. 2014, 81, 444-456. [CrossRef]

2. Costanzo, V.; Evola, G.; Marletta, L. Energy savings in buildings or UHI mitigation? Comparison between green roofs and cool roofs. Energy Build. 2016, 114, 247-255. [CrossRef]

3. World Energy Outlook-Topics-IEA. Available online: https://www.iea.org/topics/world-energy-outlook (accessed on 17 February 2020).

4. Hasan, A. Optimizing insulation thickness for buildings using life cycle cost. Appl. Energy 1999, 63, 115-124. [CrossRef]

5. Sisman, N.; Kahya, E.; Aras, N.; Aras, H. Determination of optimum insulation thicknesses of the external walls and roof (ceiling) for Turkey's different degree-day regions. Energy Policy 2007, 35, 5151-5155. [CrossRef]

6. Ouldboukhitine, S.E.; Belarbi, R.; Sailor, D.J. Experimental and numerical investigation of urban street canyons to evaluate the impact of green roof inside and outside buildings. Appl. Energy 2014, 114, 273-282. [CrossRef]

7. Bowler, D.E.; Buyung-Ali, L.; Knight, T.M.; Pullin, A.S. Urban greening to cool towns and cities: A systematic review of the empirical evidence. Landsc. Urban Plan. 2010, 97, 147-155. [CrossRef]

8. Lamnatou, C.; Chemisana, D. A critical analysis of factors affecting photovoltaic-green roof performance. Renew. Sustain. Energy Rev. 2015, 43, 264-280. [CrossRef]

9. Chemisana, D.; Lamnatou, C. Photovoltaic-green roofs: An experimental evaluation of system performance. Appl. Energy 2014, 119, 246-256. [CrossRef]

10. Palermo, S.A.; Turco, M.; Principato, F.; Piro, P. Hydrological Effectiveness of an Extensive Green Roof in Mediterranean Climate. Water 2019, 11, 1378. [CrossRef]

11. Jungels, J.; Rakow, D.A.; Allred, S.B.; Skelly, S.M. Attitudes and aesthetic reactions toward green roofs in the Northeastern United States. Landsc. Urban Plan. 2013, 117, 13-21. [CrossRef] 
12. Cascone, S.; Coma, J.; Gagliano, A.; Pérez, G. The evapotranspiration process in green roofs: A review. Build. Environ. 2019, 147, 337-355. [CrossRef]

13. Barrio, E.P. Del Analysis of the green roofs cooling potential in buildings. Energy Build. 1998, 27, $179-193$. [CrossRef]

14. Nocera, F.; Gagliano, A.; Detommaso, M.; Evola, G. Thermal Behavior of an Extensive Green Roof: Numerical Simulations and Experimental Investigations International journal of heat and technology a publication of iieta. Artic. Int. J. Heat Technol. 2016, 34, 226-234.

15. Sailor, D.J. A green roof model for building energy simulation programs. Energy Build. 2008, 40, 1466-1478. [CrossRef]

16. Silva, C.M.; Gomes, M.G.; Silva, M. Green roofs energy performance in Mediterranean climate. Energy Build. 2016, 116, 318-325. [CrossRef]

17. Ferrante, P.; La Gennusa, M.; Peri, G.; Scaccianoce, G.; Sorrentino, G. Comparison between Conventional and Vegetated Roof by Means of a Dynamic Simulation. In Proceedings of the Energy Procedia; Elsevier Ltd.: Amsterdam, The Netherlands, 2015; Volume 78, pp. 2917-2922.

18. Zeng, C.; Bai, X.; Sun, L.; Zhang, Y.; Yuan, Y. Optimal parameters of green roofs in representative cities of four climate zones in China: A simulation study. Energy Build. 2017, 150, 118-131. [CrossRef]

19. Ávila-Hernández, A.; Simá, E.; Xamán, J.; Hernández-Pérez, I.; Téllez-Velázquez, E.; Chagolla-Aranda, M.A. Test box experiment and simulations of a green-roof: Thermal and energy performance of a residential building standard for Mexico. Energy Build. 2020, 209, 109709. [CrossRef]

20. Huang, Y.; Chen, C.; Liu, W. Thermal performance of extensive green roofs in a subtropical metropolitan area. Energy Build. 2018, 159, 39-53. [CrossRef]

21. Collins, S.; Kotze, D.J.; Lü, X.; Kuoppam, K. Thermal behavior of green roofs under Nordic winter conditions. Build. Environ. 2017, 122, 206-214. [CrossRef]

22. Jaffal, I.; Ouldboukhitine, S. A comprehensive study of the impact of green roofs on building energy performance. Renew. Energy 2012, 43. [CrossRef]

23. Congedo, P.M.; Baglivo, C.; Centonze, G. Walls comparative evaluation for the thermal performance improvement of low-rise residential buildings in warm Mediterranean climate. J. Build. Eng. 2020, 28, 101059. [CrossRef]

24. Kalmár, F. Summer operative temperatures in free running existing buildings with high glazed ratio of the facades. J. Build. Eng. 2016, 6, 236-242. [CrossRef]

25. Ascione, F.; Bianco, N.; De' Rossi, F.; Turni, G.; Vanoli, G.P. Green roofs in European climates. Are effective solutions for the energy savings in air-conditioning? Appl. Energy 2013, 104, 845-859. [CrossRef]

26. Gotham Greens: Brooklyn's New High-Tech Rooftop Farm. Available online: https://www.fastcompany. com/1678197/gotham-greens-brooklyns-new-high-tech-rooftop-farm (accessed on 17 February 2020).

27. The Vinegar Factory_Eli Zabar EliZabar.com. Available online: https://www.elizabar.com/The-VinegarFactory.aspx (accessed on 17 February 2020).

28. Sky Vegetables. Available online: http://www.skyvegetables.com/ (accessed on 6 December 2019).

29. NYC Rooftop Hydroponic Garden Classroom Urban Farm Greenhouse. Available online: https://www. urbangardensweb.com/2011/11/16/nyc-classroom-in-an-urban-rooftop-farm/ (accessed on 6 December 2019).

30. Developer Raises the Bar in the Bronx|Architect Magazine. Available online: https://www.architectmagazine. com/technology/developer-raises-the-bar-in-the-bronx_o (accessed on 6 December 2019).

31. Caplow, T.; Nelkin, J. Building-integrated greenhouse systems for low energy cooling. In Proceedings of the 2nd PALENC/28th AIVC Conference on Building Low Energy Cooling and Advanced Ventilation Technologies, Crete Island, Greece, 27-29 September 2007; Volume 1, pp. 172-176.

32. Nadal, A.; Llorach-Massana, P.; Cuerva, E.; López-Capel, E.; Montero, J.I.; Josa, A.; Rieradevall, J.; Royapoor, M. Building-integrated rooftop greenhouses: An energy and environmental assessment in the mediterranean context. Appl. Energy 2017, 187, 338-351. [CrossRef]

33. Nadal, A.; Rodríguez-Cadena, D.; Pons, O.; Cuerva, E.; Josa, A.; Rieradevall, J. Feasibility assessment of rooftop greenhouses in Latin America. The case study of a social neighborhood in Quito, Ecuador. Urban For. Urban Green. 2019, 44, 126389. [CrossRef]

34. Astee, L.Y.; Kishnani, N.T. Building integrated agriculture utilising rooftops for sustainable food crop cultivation in Singapore. J. Green Build. 2010, 5, 105-113. [CrossRef] 
35. Benni, S.; Tassinari, P.; Barbaresi, A.; Torreggiani, D. Efficacy of greenhouse natural ventilation : Environmental monitoring and CFD simulations of a study case Efficacy of greenhouse natural ventilation : Environmental monitoring and CFD simulations of a study case. Energy Build. 2016, 7, 117-132.

36. WUFI (en). Available online: https://wufi.de/en/ (accessed on 11 December 2019).

37. Gholami, M.; Mofidi Shemirani, M.; Fayaz, R. A modelling methodology for a solar energy-efficient neighbourhood. Smart Sustain. Built Environ. 2018, 7, 117-132. [CrossRef]

38. Bueno, B.; Norford, L.; Hidalgo, J.; Pigeon, G. The urban weather generator. J. Build. Perform. Simul. 2013, 6, 269-281. [CrossRef]

39. Direct Data Access-Dexter System Hydro-Weather-Climate|Arpae. Available online: https://www.arpae.it/ dettaglio_generale.asp?id=3284\&idlivello=1625 (accessed on 17 February 2020).

40. Kumar, R.; Kaushik, S.C. Performance evaluation of green roof and shading for thermal protection of buildings. Build. Environ. 2005, 40, 1505-1511. [CrossRef]

41. Busser, T.; Berger, J.; Piot, A.; Pailha, M.; Woloszyn, M.; Experimental, M.W. Experimental Validation of Hygrothermal Models for Building Materials and Walls: An Analysis of Recent Trends; HAL: Lyon, France, 2018.

42. Frankenstein, S.; Koenig, G.G. Fast All-Season Soil STrength (FASST); US Army Corps of Engineers: Washington, DC, USA, 2004.

43. EnergyPlus Documentation Engineering Reference. Available online: https://energyplus.net/sites/default/ files/pdfs_v8.3.0/EngineeringReference.pdf (accessed on 19 April 2020).

44. Corrado, V.; Ballarini, I.; Corgnati, S.P. Typology Approach for Building Stock National Scientific Report on the TABULA activities in Italy; Politecnico di Torino-Dipartimento Energia: Torino, Italy, 2012; ISBN 9788882020392.

45. Hirano, Y.; Ihara, T.; Gomi, K.; Fujita, T. Simulation-based evaluation of the effect of Green Roofs in Office Building Districts on Mitigating the Urban Heat Island effect and reducing CO2 emissions. Sustainability 2019, 11, 2055. [CrossRef]

46. Barbaresi, A.; Dallacasa, F.; Torreggiani, D.; Tassinari, P. Retrofit interventions in non-conditioned rooms: Calibration of an assessment method on a farm winery. J. Build. Perform. Simul. 2017, 10, 91-104. [CrossRef]

47. Barbaresi, A.; Torreggiani, D.; Benni, S.; Tassinari, P. Underground cellar thermal simulation: Definition of a method for modelling performance assessment based on experimental calibration. Energy Build. 2014, 76, 363-372. [CrossRef]

(C) 2020 by the authors. Licensee MDPI, Basel, Switzerland. This article is an open access article distributed under the terms and conditions of the Creative Commons Attribution (CC BY) license (http://creativecommons.org/licenses/by/4.0/). 